\title{
INCIDENCE AND POSSIBLE RELATION TO ATHETOSIS OF NEONATAL JAUNDICE OF UNKNOWN AETIOLOGY*
}

BY

\author{
DYRE TROLLE \\ From the University Department of Obstetrics and Gynaecology, Rigshospitalet, Copenhagen, Denmark
}

(RECEIVED FOR PUBLICATION JUNE 26, 1963)

It is still not clear whether jaundice of unknown aetiology, developing during the neonatal period, is of significance for the subsequent development of athetosis and related diseases. In a previous study (Trolle, 1961), the author calculated that among children who have had neonatal jaundice of unknown aetiology, athetosis of later onset is so uncommon that the decision to perform an exchange transfusion merely on the basis of an arbitrarily selected bilirubin value must be regarded as unjustified. As an example, it was calculated that if routine exchange transfusion were performed on the indication of a bilirubin value of $20 \mathrm{mg} . / 100 \mathrm{ml}$. and over, a total of 2,140 transfusions would have been performed in mature infants in order to save one from athetosis, while there is a present risk that 21 would have died as a result of the exchange. In the case of prematures, 92 exchange transfusions would have been necessary in order to save one child from athetosis, but with the present risk four would have died as a result of the transfusion. The criterion for exchange transfusion cannot therefore be based only on the serum bilirubin value.

In obstetric departments and children's departments, this question of exchange transfusion in the newborn suffering from jaundice of unknown aetiology is constantly arising. In what follows, therefore, three questions will be discussed. First, since the cause of jaundice in each individual infant appears to be unknown, is it the result of a number of known clinical factors? Second, in how many cases can the jaundice be considered to play a role in the subsequent development of athetosis? Third, why do some jaundiced newborn infants subsequently develop athetosis, while others, equally or more jaundiced, do not?

To elucidate the above topics, the serum bilirubin values have been systematically determined in all

* This investigation was in part supported by PHS research grant B-2408 from the National Institute of Neurological Diseases and Blindness, U.S. Public Health Service. clinically jaundiced children born during a two-year period (April 1, 1960 to March 31, 1962). Since values below $8-9 \mathrm{mg} . / 100 \mathrm{ml}$. cannot be expected to cause clinical jaundice (Larsen and With, 1943), information is given only on the incidence of jaundice with serum bilirubin values of $10 \mathrm{mg}$./ $100 \mathrm{ml}$. or more. The determinations were made on heel blood taken daily and sometimes several times a day. The micromethod used (Jendrassik and Groof) gives the total bilirubin concentration. The analyses were done at the Central Laboratory of the University Hospital.

In addition, serological examinations were carried out on all jaundiced children and their mothers at the Blood Bank of the University Hospital. Further details are given in an earlier paper (Trolle, 1961).

The patients admitted to our department are in many ways selected. There is, for instance, a high number of premature births and complicated cases (excluding mothers with diabetes and heart failure).

The jaundice of the newborn occurring in the two-year period was caused either by rhesus incompatibility or by $\mathrm{ABO}$ and other blood-group incompatibility, or its aetiology was unknown. No cases of obliteration of the bile-ducts were seen.

During this time there were 3,846 liveborn single births weighing more than $650 \mathrm{~g}$. As a prophylactic measure all the newborn babies were given $2.5 \mathrm{mg}$. menadione intramuscularly immediately after birth. If antibiotics were needed, prophylactically or therapeutically, penicillin was used, but never sulphur preparations. Children born prematurely were placed in an incubator for a few hours only, but oxygen was given through a funnel for some days.

Of the 3,846 liveborn single births, 300 had haemolytic disease due to rhesus, $\mathrm{ABO}$ and/or other blood-group incompatibility. These 300 newborn will not be discussed further. It is worth mentioning that $45 \%$ of the newborn babies with jaundice of unknown aetiology belonged to blood group $\mathrm{O}$, which is the same percentage as found in the whole population of Denmark. 
TABLE 1

PERCENTAGE OF BABIES WITH JAUNDICE OF UNKNOWN AETIOLOGY AMONG NEWBORNS SURVIVING FIRST WEEK OF LIFE

\begin{tabular}{|c|c|c|c|c|}
\hline \multirow{2}{*}{$\begin{array}{c}\text { Total Number of } \\
\text { Newborns Surviving } \\
\text { First Week }\end{array}$} & \multirow{2}{*}{ Birth Weight (g.) } & \multicolumn{3}{|c|}{ Percentage of Babies With Serum Bilirubin Values of } \\
\hline & & $10 \mathrm{mg} . / 100 \mathrm{ml}$. and over & $15 \mathrm{mg} . / 100 \mathrm{ml}$. and over & $20 \mathrm{mg} . / 100 \mathrm{ml}$. and over \\
\hline $\begin{array}{r}5 \\
36 \\
88 \\
239 \\
790 \\
2,009 \\
259\end{array}$ & $\begin{array}{l}>\quad 650 \leq 1,000 \\
>1,000 \leq 1,500 \\
>1,500 \leq 2,000 \\
>2,000 \leq 2,500 \\
>2,500 \leq 3,000 \\
>3,500 \leq 4,000 \\
>4,000\end{array}$ & $\begin{array}{l}40 \cdot 0 \\
86 \cdot 1 \\
72 \cdot 8 \\
49 \cdot 4 \\
33 \cdot 8 \\
22 \cdot 6 \\
12 \cdot 7\end{array}$ & $\begin{array}{r}20 \cdot 0 \\
41 \cdot 7 \\
37 \cdot 9 \\
25 \cdot 5 \\
17 \cdot 9 \\
10 \cdot 1 \\
6 \cdot 6\end{array}$ & $\begin{aligned} 0 \\
16 \cdot 7 \\
18 \cdot 2 \\
5 \cdot 9 \\
6 \cdot 3 \\
3 \cdot 4 \\
1 \cdot 2\end{aligned}$ \\
\hline $\begin{array}{r}365 \\
3,058\end{array}$ & $>2650 \leq 2,500$ & $\begin{array}{l}58 \cdot 4 \\
24 \cdot 7\end{array}$ & $\begin{array}{l}30 \cdot 2 \\
11 \cdot 8\end{array}$ & $\begin{array}{l}9 \cdot 8 \\
4 \cdot 0\end{array}$ \\
\hline 3,423 & $>\quad 650$ & $28 \cdot 3$ & $13 \cdot 7$ & $4 \cdot 6$ \\
\hline
\end{tabular}

The present material thus comprises 3,546 liveborn single births weighing more than $650 \mathrm{~g}$., and of these 975 developed jaundice of unknown aetiology, i.e. had a serum bilirubin level of $10 \mathrm{mg} . / 100 \mathrm{ml}$. and over, during the first week of life (a few newborns with a serum bilirubin level of less than $10 \mathrm{mg}$./ $100 \mathrm{ml}$. are thus not included). Four of the 975 jaundiced newborn and 119 of the remaining 2,571 died during the first week of life.*

During the first six months of the period of the investigation, exchange transfusion was performed as routine with a serum bilirubin value $20 \mathrm{mg}$./ $100 \mathrm{ml}$. and over (see previous study, Trolle, 1961). During the next 18 months, in which only two newborns had exchange transfusions, the highest serum bilirubin value was $33.2 \mathrm{mg}$. (fifth day) among the mature newborn and $25 \cdot 2 \mathrm{mg} . / 100 \mathrm{ml}$. (sixth day) among prematures. None of the newborns surviving the first week of life showed any signs of kernikterus and all were discharged without or with only slight jaundice, except eight weighing less than 2,000 g. who died during the second week of life. No kernikterus was demonstrated at autopsy (see later). (Among the four newborns with jaundice of unknown aetiology who died in the first week of life, kernikterus was suspected in one as a result of the clinical examination. This was confirmed at autopsy (see later).)

\section{Does Jaundice of Unknown Origin Depend on a Series of Known Clinical Factors?}

In the newborn surviving the first week of life the incidence of jaundice of unknown aetiology is $28 \cdot 3 \%$.

* This big difference in mortality is a consequence of the fact that of the 119 newborn who died during the first week of life, 93, or $78 \%$, died less than 48 hours after birth, and 109 , or $92 \%$, died less than 72 hours after birth. At this stage, pronounced jaundice of unknown aetiology is only rarely present. After 72 hours, there were 10 deaths $(8 \%$ of the 119 deaths) out of the 2,571 non-jaundiced newborn, i.e. $0.4 \%$, and three deaths out of the 975 jaundiced newborn, i.e. $0.3 \%$. In only one out of all these neonatal deaths was kernikterus demonstrated at autopsy: this newborn had jaundice of unknown aetiology, and will be discussed later.
Table 1 shows the incidence of the degree of jaundice in various weight groups. From this Table it is obvious that the percentage of jaundiced newborn babies increases with falling birth weight, except in those weighing between 650 and $1,000 \mathrm{~g}$. This, however, can undoubtedly be explained by the low number of cases, namely five newborn in all, of whom two had jaundice.

The cause of the rise in incidence with falling birth weight is probably an enzyme deficiency in the liver cells. The excretion of the indirect bilirubin requires two different enzymes, namely uridinediphosphate-glucuronic acid dehydrogenase and glucuronyl transferase. Both these enzymes are present in the microsomal fraction of the liver and appear late in the foetal development and only in small amounts. After birth the enzymes increase in number and activity (Brown, Zuelzer and Burnett, 1958; Richter, 1961a).

Whether other clinical factors are of importance in the incidence of jaundice of unknown aetiology is examined in Table 2. In relation to the total material, there is an apparent variation in the incidence of jaundice for some of the conditions mentioned in column 1 (Table 2), but the only statistically significant figures are those for newborn babies weighing $2,500 \mathrm{~g}$. or less, of mothers with toxaemia $(p<0.003)$. However, babies of toxaemic mothers most often weigh less than other babies of the same gestational age, and this may be an explanation, or part of one.

If one compares the incidence of jaundice in boys and girls, the difference is statistically significant for all three weight groups ( $\leqslant \leqslant 0 \cdot 00006)$. Wood, Culley, Waterhouse and Powell (1962) were not able to demonstrate a significant difference.

Early or late clamping of the umbilical cord has no influence on the occurrence of jaundice (investigations by T. Tobiassen, 1962, unpublished).

There seems to be a slight seasonal fluctuation. 
TABLE 2

NUMBER AND PERCENTAGE WITH JAUNDICE OF UNKNOWN AETIOLOGY AMONG NEWBORNS SURVIVING FIRST WEEK OF LIFE, IN RELATION TO VARIOUS OTHER FACTORS

\begin{tabular}{|c|c|c|c|c|c|c|c|c|c|c|c|c|c|}
\hline & & & & & & & & \multicolumn{6}{|c|}{ Birth Weight of } \\
\hline & & & & & & & & \multicolumn{2}{|c|}{ All Infants $(>650 \mathrm{~g})}$. & \multicolumn{2}{|c|}{$>2,500 \mathrm{~g}$} & \multicolumn{2}{|c|}{$2,500 \mathrm{~g}$. or less } \\
\hline & & & & & & & & No. & $\%$ Jaundiced & No. & $\%$ Jaundiced & No. & $\%$ Jaundiced \\
\hline Total material & . & $\ldots$ & $\ldots$ & & & & & \multirow{11}{*}{$\begin{array}{r}971 \\
418 \\
553 \\
483 \\
423 \\
52 \\
487 \\
750 \\
20 \\
55 \\
42 \\
25\end{array}$} & \multirow{11}{*}{$\begin{array}{l}28 \cdot 4 \\
24 \cdot 9 \\
31 \cdot 8 \\
27 \cdot 1 \\
27 \cdot 7 \\
21 \cdot 8 \\
29 \cdot 0 \\
28 \cdot 0 \\
29 \cdot 9 \\
25 \cdot 1 \\
26 \cdot 6 \\
23 \cdot 8\end{array}$} & \multirow{11}{*}{$\begin{array}{r}756 \\
322 \\
434 \\
391 \\
345 \\
47 \\
366 \\
584 \\
16 \\
36 \\
23 \\
12\end{array}$} & \multirow{11}{*}{$\begin{array}{l}24 \cdot 7 \\
21 \cdot 5 \\
27 \cdot 8 \\
24 \cdot 2 \\
24 \cdot 8 \\
21 \cdot 7 \\
25 \cdot 0 \\
24 \cdot 4 \\
26 \cdot 2 \\
19 \cdot 4 \\
18 \cdot 3 \\
14 \cdot 8\end{array}$} & \multirow{11}{*}{$\begin{array}{r}215 \\
96 \\
119 \\
92 \\
78 \\
5 \\
121 \\
166 \\
4 \\
19 \\
19 \\
13\end{array}$} & \multirow{11}{*}{$\begin{array}{l}59 \cdot 0 \\
48 \cdot 0 \\
67 \cdot 2 \\
54 \cdot 8 \\
55 \cdot 2 \\
22 \cdot 7 \\
57 \cdot 1 \\
60 \cdot 1 \\
66 \cdot 6 \\
57 \cdot 6 \\
59 \cdot 4 \\
54 \cdot 1\end{array}$} \\
\hline Girls & $\ldots$ & $\ldots$ & $\cdots$ & $\therefore$ & $\ddot{m}$ & $\ddot{m}$ & $\because$ & & & & & & \\
\hline Boys & $\because$ & $\cdots$ & $\because$ & $\cdots$ & $\cdots$ & $\cdots$ & $\cdots$ & & & & & & \\
\hline Primiparae & . & $\ldots$ & $\because$ & $\cdots$ & $\cdots$ & $\cdots$ & $\cdots$ & & & & & & \\
\hline Toxaemia . . & & & $\cdots$ & $\cdots$ & $\cdots$ & $\cdots$ & & & & & & & \\
\hline Normal spontar & eous b & $\mathrm{rt} \dot{\mathrm{h}}$ & $\cdots$ & $\cdots$ & $\cdots$ & 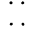 & $\cdots$ & & & & & & \\
\hline Trilene during & rth & & . & $\ldots$ & $\cdots$ & $\cdots$ & $\ldots$ & & & & & & \\
\hline Caesarean secti & n befo & e birth & .. & .. & .. & .. & & & & & & & \\
\hline Caesarean secti & $n$ durir & g birth & & $\ddot{m}$ & $\cdots$ & 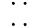 & $\because$ & & & & & & \\
\hline Danger of deatl & of inf & nt durin & ig birth & & $\cdots$ & $\cdots$ & $\cdots$ & & & & & & \\
\hline Asphyxia neona & orum & . & . & & $\cdots$ & $\cdots$ & $\cdots$ & & & & & & \\
\hline
\end{tabular}

During the months of April, May and June the number of babies with jaundice is lower than during October, November and December, but the present numbers are too small to validate this observation. Wood et al. (1962) did not find any seasonal fluctuation.

It might be possible that the administration of $2.5 \mathrm{mg}$. menadione to the babies immediately after birth was a cause of the jaundice. Dyggve (1960) showed that if $10 \mathrm{mg}$. menadione were given to newborn babies, $19 \cdot 2 \%$ reached a serum bilirubin level of more than $20 \mathrm{mg} . / 100 \mathrm{ml}$, but if $1 \mathrm{mg}$. $\mathrm{K}_{1}$ vitamin (which is non-toxic) were given, only $12.3 \%$ reached the same level. In the present material only $2.5 \mathrm{mg}$. menadione was used, and as seen in Table 1 only $9.8 \%$ of the prematures had a serum bilirubin level of $20 \mathrm{mg} . / 100 \mathrm{ml}$. or more. The administration of menadione, therefore, cannot explain the appearance of jaundice.

In $60-63 \%$ of those jaundiced, mature as well as premature newborn babies, the maximum serum bilirubin value $(10,15$ and $20 \mathrm{mg} . / 100 \mathrm{ml}$. respectively) was reached on the fourth or fifth day of life. If we include the third and sixth day of life we find that in $91-93 \%$ of the cases the maximum serum bilirubin value appears within these four days, still independent of maturity and the level of the serum bilirubin. (A more detailed analysis is shown in Fig. 1.) The duration of the jaundice, on the other hand, depends on the magnitude of the maximum serum bilirubin. The higher this value, the longer the jaundice persists.

\section{Can Jaundice of Unknown Aetiology be Considered to Play a Role in Subsequent Development of Athetosis?}

Discussions on the significance of jaundice of unknown aetiology in the development of kernikterus continue (e.g. A Conference Presented by the
American Academy for Cerebral Palsy, 1961). Most authors conclude that it is impossible to fix a critical serum bilirubin value, partly because very low values may cause kernikterus, partly because high values most often do not cause kernikterus. Other factors besides bilirubin seem to be of importance.

Kernikterus is a result of the deposition of indirect bilirubin in the brain, especially in the extrapyramidal system. It may seem contradictory that

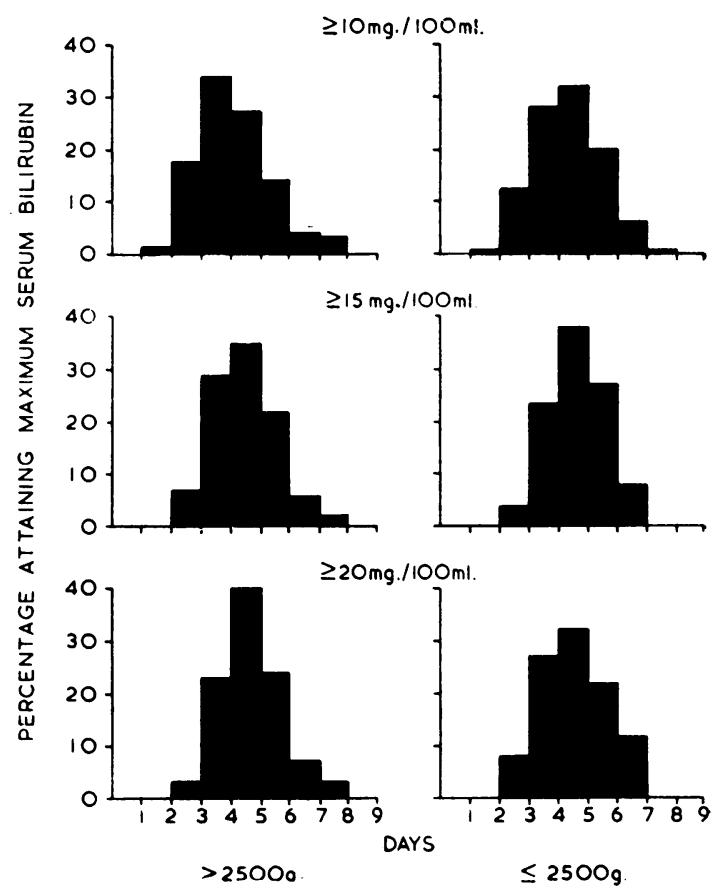

FIGURE.-The day of maximum serum bilirubin in newborn babies of birth weights over $2,500 \mathrm{~g}$. and $2,500 \mathrm{~g}$. or less. Ordinate: Percentage of newborn who have attained their maximum serum bilirubin value. 
TABLE 3

PERCENTAGE INCIDENCE OF JAUNDICE OF UNKNOWN ORIGIN IN CHILDREN SURVIVING FIRST WEEK OF LIFE*

\begin{tabular}{|c|c|c|c|c|}
\hline \multirow[t]{2}{*}{ Birth Weight (g.) } & \multirow{2}{*}{$\begin{array}{c}\text { Jaundice of Unknown Origin } \\
\text { Found Retrospectively in } \\
\text { Plum's Material of Children } \\
\text { Subsequently Developing } \\
\text { Athetosis }(\%)\end{array}$} & \multicolumn{3}{|c|}{$\begin{array}{c}\text { Jaundice of Unknown Origin During } \\
\text { Neonatal Period in Two-year Material } \\
\text { From Obstetrical Dept. A }(\%)\end{array}$} \\
\hline & & $10 \mathrm{mg} . / 100 \mathrm{ml}$. or over & $15 \mathrm{mg} . / 100 \mathrm{ml}$. and over & $20 \mathrm{mg} . / 100 \mathrm{ml}$. and over \\
\hline Over 2,500 or less & $\begin{array}{l}62 \\
31\end{array}$ & $\begin{array}{l}58 \\
25\end{array}$ & $\begin{array}{l}30 \\
12\end{array}$ & $\begin{array}{r}10 \\
4\end{array}$ \\
\hline
\end{tabular}

the indirect bilirubin in newborn babies with jaundice of unknown aetiology can pass easily into the subcutaneous tissue, but only rarely into the brain. This phenomenon, however, is explained by the fact that the capillaries in the brain have special features of their own (Crone, 1961). The bloodbrain barrier is peculiar in that its permeability is different from that of other tissue.

We can only guess why the indirect bilirubin, albeit rarely, does pass the blood-brain barrier in newborn babies with jaundice of unknown aetiology. Some authors suppose that the barrier can be passed only in the case of an unfavourable ratio between the indirect bilirubin and the serum proteins. The unfavourable ratio may be caused by low levels of serum proteins or by displacement of the indirect bilirubin from the serum proteins by ketone bodies, unesterified fatty acids and sulphonamides (Day, 1961). Other authors suppose that the capillary walls are injured either directly by circulating substances or indirectly by primary damage to the glial cells which closely invest the capillaries of the brain. (See also the discussion in A Conference Presented by the American Academy for Cerebral Palsy (1961) and Richter (1961b).

Since rhesus-sensitized newborn babies easily develop kernikterus if exchange transfusions are withheld, another explanation for the permeability of the blood-brain barrier must exist. Pentschew (1948) thinks that the antibodies damage the barrier, an explanation in line with the results of Skoog's animal experiments with intravasal injection of Forssman-antigen (1939).

If the above-mentioned account of blood-brain barrier behaviour is correct, there is a most important difference between blood-group-sensitized newborn babies with jaundice and babies with jaundice of unknown aetiology. Even before birth the former possess the factor that damages the blood-brain barrier, while only as an exception do the latter acquire a damaging factor during or after birth. But for both groups it is true to say that without serum bilirubinaemia there is no kernikterus.

It has been customary so far to group newborn babies with jaundice of unknown aetiology together with blood-group-sensitized babies, and it is, therefore, understandable that the bilirubinaemia per se is said to be important for the later development of athetosis.

But newborn babies with jaundice of unknown aetiology should also be compared with babies without jaundice. The latter may also develop athetosis, and here the aetiology is mainly asphyxia, particularly in combination with difficult delivery and/or attacks of cyanosis and convulsions during the first days of life; in a few cases the aetiology is malformation of the brain, and finally, in some, the aetiology is unknown (Hansen, 1960). It is therefore justifiable to ask whether athetosis developing in babies with jaundice of unknown aetiology has the same origin as athetosis without jaundice.

In order to answer this question, we may use Plum's material from 1957, on the aetiology of congenital athetosis. The blood-group-sensitized newborn babies must first be excluded; this can be done by means of Plum's Tables 1 and 2 . The following table (Table 3) can then be set up for comparison. In Plum's material, the jaundice of unknown origin has mainly been of 14 days' duration (Plum's Fig. 1). There seems to be good agreement between Plum's material and the material of Obstetric Department A with regard to the incidence of jaundice of unknown origin.

Perhaps, then, jaundice of unknown origin has no aetiological significance for the subsequent development of athetosis. To answer this question we may once more examine Plum's material. From this it is evident that an aetiological relation exists between jaundice due to blood-group incompatibility and the subsequent development of athetosis. Other forms of cerebral palsy are probably not due to neonatal jaundice. Furthermore, it is possible from Plum's material (Table 1 and Table 8) to calculate the incidence of athetosis in the children with cerebral palsy who at birth showed: (a) jaundice due to blood-group incompatibility, (b) jaundice of unknown aetiology and (c) no jaundice (Table 4). 
TABLE 4

PERCENTAGE OF ATHETOSIS IN PLUM'S MATERIAL OF CHILDREN WITH CEREBRAL PALSY

\begin{tabular}{c|c|c|c}
\hline $\begin{array}{c}\text { Birth } \\
\text { Weight } \\
\text { (g.) }\end{array}$ & $\begin{array}{c}\text { Group 1: } \\
\text { Jaundice Due } \\
\text { to Blood-group } \\
\text { Incom- } \\
\text { patibility } \\
(\%)\end{array}$ & $\begin{array}{c}\text { Group 2: } \\
\text { Jaundice of } \\
\text { Unknown } \\
\text { Aetiology } \\
(\%)\end{array}$ & $\begin{array}{c}\text { Group 3: } \\
\text { No Jaundice } \\
(\%)\end{array}$ \\
\hline $\begin{array}{c}\text { 2,500 or less } \\
\text { Over 2,500 }\end{array}$ & 100 & 29 & 9 \\
\hline
\end{tabular}

A significant difference is seen in the numbers of those with athetosis in the first and the third groups (Table 4). The second group (jaundice of unknown aetiology) lies between the other two.

Birth Weight of 2,500 g. and Less. In Group 2 (jaundice of unknown aetiology), 29 out of 100 children with cerebral palsy have athetosis, but only nine out of 100 in Group 3 (no jaundice). It may thus be presumed that the aetiology of the athetosis in about nine out of a 100 of the children in Group 2 is the same as in Group 3 and thus has no relation to the jaundice. For the remaining 20 children in Group 2 athetosis is a consequence of the jaundice. In other words, among premature babies with athetosis and a history of jaundice of unknown aetiology during the first week of life, two-thirds have developed athetosis as a result of the jaundice.

Birth Weight greater than 2,500 g. Using the same argument for the children with a birth weight greater than 2,500 g., the following conclusions may be drawn. Among children with athetosis and a history of jaundice of unknown aetiology during the first week of life, little more than one-half developed athetosis as a consequence of the jaundice.

If this assumption holds, it should be the duty of the clinician to select those jaundiced newborn babies with a blood-brain barrier allowing indirect bilirubin to pass, and to carry out exchange transfusion in them. But we do not know at present how to find these and it is not justifiable to carry out exchange transfusion as a routine in all jaundiced newborn babies exceeding a fixed serum bilirubin value. Attention should undoubtedly be paid in particular to anoxic newborn babies, especially where labour has been difficult and/or they develop attacks with cyanosis and convulsions during the first few days of life, or show signs of kernikterus. The rate at which the serum bilirubin rises may also be of significance. Only one of the total of 975 newborn babies with jaundice of unknown origin showed a bilirubin value above $20 \mathrm{mg} . / 100 \mathrm{ml}$. during the first 48 hours after birth (weight $1,750 \mathrm{~g}$., prolonged labour, forceps delivery on account of threatening intrauterine foetal death). This baby showed no sign of kernikterus, and an exchange transfusion was performed on the indication of a rapid rise in bilirubin alone. The child was well on discharge from hospital. The other babies undergoing exchange transfusion during the last 18 months showed no sign of kernikterus either $(2,750 \mathrm{~g}$., delivered by vacuum extractor because of slight pre-eclampsia in the mother). Exchange transfusion was done when the serum bilirubin rose to $33.2 \mathrm{mg}$./100 ml. (fifth day), because of the potential danger.

\section{Autopsies}

Eight newborn babies, three girls and five boys, with a birth weight between 750 and 1,900 g., died in the second week of life. The serum bilirubin value did not exceed $24 \mathrm{mg}$. $100 \mathrm{ml}$. At the autopsies the brain was immediately fixed in formalin and subsequently examined macro- and microscopically. In none was kernikterus suspected clinically, nor was it demonstrated at autopsy.

Finally, the four newborn infants with jaundice of unknown aetiology who died in the first week of life should be mentioned.

(1) Male, weighing 1,900 g., died 45 hours after birth; the maximum serum bilirubin was 11.5 mg. $/ 100 \mathrm{ml}$.

(2) Male, weighing 1,600 g., died 158 hours after birth; the maximum serum bilirubin was $25 \cdot 1$ mg./100 ml.

(3) Male, weighing 1,200 g., died 115 hours after birth; maximum serum bilirubin $22.6 \mathrm{mg}$. $/ 100 \mathrm{ml}$.

(4) Female, weighing 1,050 g., died 97 hours after birth; maximum serum bilirubin $25.5 \mathrm{mg} . / 100 \mathrm{ml}$.

The kernikterus suspected clinically in no. 2 was confirmed at autopsy.

\section{Conclusion}

The two-year period of study falls into two sections. During the first six months, exchange transfusions were made if the bilirubin value was greater than $20 \mathrm{mg} . / 100 \mathrm{ml}$. (Trolle, 1961). On the basis of the conclusions discussed here, we altered our point of view, and during the next 18 months we carried out exchange transfusion in only two newborn babies.

None of the 963 newborn babies discharged from the department over the two-year period showed any sign of kernikterus during their stay in hospital or when they left. Kernikterus was suspected clinically in one of those dying during the last 18 months, and this was confirmed at autopsy, but no kernikterus was demonstrated in any of the other 11 deaths. 
Assuming the correctness of our clinical evaluation of the newborn, the present study shows that exchange transfusion should have been performed in one of the newborn from the last 18 months of the period, the premature infant who died from kernikterus. The wisdom of carrying out an exchange transfusion in the premature infant who has a rapid rise in serum bilirubin value and in the mature infant with a high serum bilirubin blood value is debatable.

Exchange transfusion is thus rarely indicated and this conclusion is in agreement with the author's conclusions (Trolle, 1961). The calculation made then, however, was based on a serum bilirubin value of $20 \mathrm{mg} . / 100 \mathrm{ml}$. or more. But it is known also that lower values than this may cause athetosis (Killander, Müller-Eberhard and Sjölin, 1960). It would, therefore, be more correct to calculate the necessity of replacement transfusion for all newborn babies with jaundice of unknown origin, i.e. all those with a serum bilirubin value of $10 \mathrm{mg}$. $/ 100 \mathrm{ml}$. or more. At the same time, however, from the present study we see that in infants with a history of jaundice of unknown aetiology during the first week of life, any athetosis that develops subsequently is due to the jaundice in only two-thirds of the athetosis cases with a birth weight $2,500 \mathrm{~g}$. or less, and in only a little more than one-half of the athetosis cases with a birth weight greater than $2,500 \mathrm{~g}$.

Using Table 1 from Trolle (1961), Table 1 in the present study and the premises put forward, the following calculation can be made for children of birth weight $2,500 \mathrm{~g}$. or less. The risk of subsequent athetosis in infants with a history of jaundice of unknown aetiology in the first week of life is $0.12 \%$ of all births of $2,500 \mathrm{~g}$. or less, i.e. $1 \cdot 2$ per 1,000 births. Since the frequency of jaundice of unknown origin (serum bilirubin value $10 \mathrm{mg}$./ $100 \mathrm{ml}$. or more) is $58.4 \%$, the risk of subsequent athetosis among newborn babies with a history of jaundice of unknown aetiology in the first week of life is $0 \cdot 21 \%$, i.e. $2 \cdot 1$ per 1,000 cases. However, the athetosis is due to jaundice in only two-thirds of the cases, so that the risk becomes $1 \cdot 4$ per 1,000 . In other words, exchange transfusion should be done in 1-2 per 1,000 newborn babies, 2,500 g. or less, with jaundice of unknown aetiology. In the case of newborn babies with birth weight greater than $2,500 \mathrm{~g}$., the corresponding figures are: $0 \cdot 0028 \%$ of all babies with a birth weight greater than 2,500 g., i.e. $0 \cdot 28$ per 10,000 births. Only $24 \cdot 7 \%$ of these births have jaundice of unknown aetiology, so that the risk of subsequent athetosis among newborn babies with a history of jaundice of unknown aetiology is $1 \cdot 13$ per 10,000 . Only in about one-half of the cases, however, is the athetosis due to jaundice. In other words, exchange transfusion should be done in 0-1 per 10,000 newborn babies with jaundice of unknown origin, who have a birth weight greater than $2,500 \mathrm{~g}$.

Mores, Fargašová and Minař́ková (1959) concluded from their material that prophylactic exchange transfusions were not indicated in newborn babies with hyperbilirubinaemia without isoimmunization. Shiller and Silverman (1961) have followed up a consecutive number of premature babies $(2,000 \mathrm{~g}$. and less) with or without jaundice of unknown aetiology. The children were re-examined when 3 years old by paediatricians, neurologists, psychologists, speech and hearing therapists and dental surgeons. The frequency of neurological deficit and mental retardation had no relation to jaundice of unknown aetiology. Bjure, Lidén, Reinand and Vestby (1961) concluded from their follow-up study of full-term newborn babies with jaundice of unknown aetiology (bilirubin $18 \mathrm{mg} . / 100 \mathrm{ml}$. or more) that hyperbilirubinaemia alone did not give rise to any cerebral lesion.

\section{Summary}

In a consecutive series of newborn babies surviving the first week of life, the incidence of jaundice of unknown aetiology was found to be $28.3 \%$ (i.e. 971 out of 3,423 ). The rise in incidence with falling birth weight is shown in Table 1. The possible influence of a number of factors on the incidence of jaundice was examined (Table 2), but only toxaemia in mothers giving birth to babies weighing $2,500 \mathrm{~g}$. or less seems to be significant, as it reduces the incidence. The incidence of jaundice was found to be significantly higher in boys than in girls.

Newborn babies with jaundice of unknown aetiology only rarely develop athetosis. The incidence of jaundice is nearly the same in a group of children with athetosis as in Obstetric Department A's material of all newborn babies (Table 3). For those who develop athetosis, jaundice of unknown aetiology can explain only some, namely, two-thirds of the children with a birth weight of $2,500 \mathrm{~g}$. or less, and a little more than one-half of the children with a birth weight greater than $2,500 \mathrm{~g}$. In the remaining cases, one-third and almost one-half respectively, the aetiology of the athetosis is assumed to be the same as in children with no jaundice.

On the basis of the results presented, it is concluded that in newborn babies with jaundice of unknown origin exchange transfusion will prevent 
kernikterus in 1-2 per 1,000 with a birth weight of $2,500 \mathrm{~g}$. or less, and in $0-1$ per 10,000 weighing more than $2,500 \mathrm{~g}$.

\section{REFERENCES}

A Conference Presented by the American Academy for Cerebral Palsy (1961). Kernicterus and its Importance in Cerebral Palsy. (Eleventh Annual Meeting, New Orleans.) Charles C. Thomas, Springfield, Illinois.

Bjure, J., Lidén, G., Reinand, T. and Vestby, A. (1961). A follow-up study of hyperbilirubinaemia in full-term infants without isoimmunisation. Acta paediat. (Uppsala), 50, 437

Brown, A. K., Zuelzer, W. W. and Burnett, H. H. (1958). Studies on the neonatal development of the glucuronide conjugating system. J. clin. Invest., 37, 332.

Crone, C. (1961). On Diffusion of Some Organic Non-electrolytes from Blood to Brain Tissue, p. 180. Ejnar Munksgaard, Copenhagen.

Day, R. L. (1961). Physiologic jaundice-1961. Pediat. Clin. N. Amer., 8, 539 .

Dyggve, H. (1960). Bilirubin studies in premature infants who received menadione derivatives or vitamin $\mathrm{K}_{1}$ at birth. Acta paediat. (Uppsala), 49, 230.

Hansen, E. (1960). Cerebral Palsy in Denmark [Acta Psychiat. (Kbh.), 35, Suppl. 146]. Einar Munksgaard, Copenhagen.
Killander, A., Müller-Eberhard, U. and Sjölin, S. (1960). Indications for exchange transfusion in newborn infants with hyperbilirubinaemia not due to Rh-immunization. Acta paediat. (Uppsala), 49, 377.

Larsen, E. H. and With, T. K. (1943). The metabolism of bile pigments in infants, with special regard to icterus neonatorum. ibid., 31, 153.

Mores, Ä., Fargašová, I. and Minaříková, E. (1959). The relation of hyperbilirubinemia in newborns without iso-immunization to kernicterus. Acta paediat. (Uppsala), 48, 590.

Pentschew, A. (1948). Encephalopathia posticterica infantum. Arch. Psychiat. Nervenkr., 180, 118.

Plum, P. (1957). Etiology of congenital athetosis. Ann. Paediat. Fenn., 3, 589

Richter, D. (1961a). Enzymic activity during early development. Brit. med. Bull., 17, 118.

- (1961b). The stability of the nervous system during development. In Ciba Foundation Symposium on Somatic Stability in the Newly Born, p. 296. Churchill, London.

Shiller, J. G. and Silverman, W. A. (1961). 'Uncomplicated' hyperbilirubinemia of prematurity. Amer. J. Dis. Child., 101, 587.

Skoog, T. (1939). Studies of a vestibular syndrome induced in guinea-pigs by allergic reaction. Acta otolaryng. (Stockh.),

Trolle, D. (1961). Discussion on the advisability of performing exchange transfusion in neonatal jaundice of unknown aetiology. Acta paediat. (Uppsala), 50, 392.

Wood, B. S. B., Culley, P. E., Waterhouse, J. A. H. and Powell, D. J. (1962). Factors influencing neonatal jaundice. Arch. Dis. Childh., 37, 371. 